\title{
Antecedents of industrial brand equity: an empirical study
}

Citation for published version (APA):

van Riel, A. C. R., Pahud de Mortanges, C. F. W., \& Streukens, A. C. P. (2004). Antecedents of industrial brand equity: an empirical study. METEOR, Maastricht University School of Business and Economics. METEOR Research Memorandum No. 011 https://doi.org/10.26481/umamet.2004011

Document status and date:

Published: 01/01/2004

DOI:

10.26481/umamet.2004011

Document Version:

Publisher's PDF, also known as Version of record

\section{Please check the document version of this publication:}

- A submitted manuscript is the version of the article upon submission and before peer-review. There can be important differences between the submitted version and the official published version of record.

People interested in the research are advised to contact the author for the final version of the publication, or visit the DOI to the publisher's website.

- The final author version and the galley proof are versions of the publication after peer review.

- The final published version features the final layout of the paper including the volume, issue and page numbers.

Link to publication

\footnotetext{
General rights Owners
rights.

- You may freely distribute the URL identifying the publication in the public portal. please follow below link for the End User Agreement:

www.umlib.nl/taverne-license

Take down policy

If you believe that this document breaches copyright please contact us at:

repository@maastrichtuniversity.nl

providing details and we will investigate your claim.
}

Copyright and moral rights for the publications made accessible in the public portal are retained by the authors and/or other copyright owners and it is a condition of accessing publications that users recognise and abide by the legal requirements associated with these

- Users may download and print one copy of any publication from the public portal for the purpose of private study or research.

- You may not further distribute the material or use it for any profit-making activity or commercial gain

If the publication is distributed under the terms of Article $25 \mathrm{fa}$ of the Dutch Copyright Act, indicated by the "Taverne" license above, 


\title{
Antecedents of industrial brand equity:
}

\section{An empirical study}

\author{
Allard C.R. van Riel*, Charles Pahud de Mortanges, Sandra Streukens \\ Department of Marketing, Maastricht University, P.O. box 616, 6200 MD Maastricht, the Netherlands
}

\begin{abstract}
Industrial branding has emerged as an important issue, allowing firms to gain substantial competitive advantage, especially in markets where product commoditization and electronic procurement are on the increase. This article proposes, and empirically validates, a theoretically structured approach to measure brand equity, its antecedents and its consequences for industrial products. The model distinguishes between product and corporate brand equity, uses buyer perceived performance on the dimensions of the marketing mix as antecedents of brand equity, and relates them to repurchase and loyalty intentions.
\end{abstract}

Keywords: Industrial brand equity, Marketing mix, Industrial relations

\footnotetext{
* Corresponding author. Tel.: +31-43-3883778; fax: +31-43-3884918;

E-mail adresses: a.vanriel@mw.unimaas.nl (A.C.R. van Riel), c.pahud@mw.unimaas.nl (C. Pahud de Mortanges),
} s.streukens@mw.unimaas.nl (S. Streukens) 


\section{Introduction}

Branding and brand management can no longer be considered the exclusive domain of consumer marketing. A recent overview of the world's 100 strongest brands not only lists Coca Cola, McDonald's and Disney, but also includes many renowned industrial brands such as Boeing, SAP, Xerox, Siemens, and GE (Interbrand, 2003). One of the reasons for the increasingly important role of industrial branding is the commoditization of many industrial products. Another reason is the growing importance of B2B buying and selling via the Internet. There is evidence that online buyers will use cues like the brand to reduce the risks involved in purchasing decisions (Hunter et al., 2004; Ulaga \& Chacour, 2001). Analogous to consumer marketing, effective branding strategies for commodity-like products might therefore yield substantial benefits (Bendixen et al., 2004). For example, Dupont, an industrial company that brands almost all the products and ingredients it manufactures, has had considerable success with brands such as Teflon, Kevlar, and Lycra. Strong brands could therefore be considered a key source of sustainable competitive advantage in B2B environments (Gordon et al., 1993; Kumar et al., 2003).

Despite these developments, and the total value of transactions in the B2B market, little empirical research has been conducted in the domain of industrial branding (Gordon et al., 1993; Low \& Blois, 2002; Mudambi, 2002; Mudambi et al., 1997; Shipley \& Howard, 1993). Driven by the recognition of a need for empirical validation, the present study will be guided by the following research question:

What is the role of brand equity in industrial purchasing?

The following interrelated sub questions have been formulated:

1) How can B2B brand equity be conceptualized and measured?

2) What are antecedents of $B 2 B$ brand equity? 
3) What are consequences of B2B brand equity?

The present article is structured as follows. First, in a review of current research indicators, antecedents and consequences of industrial brand equity are identified, and a number of hypotheses are derived with respect to their relationships. These are summarized in a theoretical model. Furthermore, a research design is presented and the structural model is validated by means of an empirical study. A presentation and discussion of the results follows. Next, the managerial implications of the findings are discussed. Finally, limitations of the research and suggestions for future research are presented.

\section{Literature Review and Development of Propositions}

\subsection{Customer Based Industrial Brand Equity}

So far, little explicit agreement exists as to the conceptualization of industrial brand equity. In consumer marketing literature, brand equity is generally defined as the added value endowed to a product as a result of past investments in the marketing of the brand (Keller, 1998). Added value of a brand is created in the mind of consumers, as a result of perceived performance on various marketing dimensions. Consequently, it has been argued that industrial brand equity could be conceptualized and measured from the perspective of the industrial buyer (Mudambi et al., 1997). Buyer-based brand equity seems a good starting point to assess industrial brand equity (Lassar et al., 1995; Wood, 2000). Therefore, a customer-based method developed in consumer research will be adapted to the specific situation of the industrial buyer.

Differences exist between end consumers and industrial buyers, in terms of the

process leading to buying decisions. On the one hand, industrial buyers are thought to be more rationally concerned with determinants like product performance, product 
quality, delivery, service and price, than end consumers (Shipley \& Howard, 1993). On the other hand, conditions are said to exist under which industrial buyers appear to make a purchase decision on the basis of the brand name instead of price, or other factors. This may occur when failure of the purchased product would have dire consequences for the buyer's organization, or for the buyer personally; when the product requires substantial service or support; when the product is complex; or when the buyer is under time and/or resource constraints (Hutton, 1997). Although procurement in industrial markets is often rational and calculative, brands could play a significant role in this process under conditions of risk. Also, more and more industrial products are purchased online through specifically designed websites (Sharma et al., 2001). In such situations, brands could be important in establishing a consideration set of potential suppliers in the mind of the buyer.

Customer based brand equity is said to exist in several interrelated dimensions: brand awareness, brand quality, brand associations and brand loyalty (Aaker, 1991; Aaker, 1996; Keller, 1993; Keller, 1998). While several of these dimensions appear directly transferable to industrial branding, others appear irrelevant. Brand awareness, i.e. the ability to recognize, or recall, that a brand is a member of a certain product category (Aaker, 1991) appears very important in industrial branding. This is because often large numbers of alternative suppliers and products must be considered and compared (Michell et al., 2001). Brand awareness thus reflects the ability to identify the brand under conditions of complexity and time pressure (Keller, 1998). Furthermore, perceived brand quality, i.e., a perception of the overall quality or superiority of a brand relative to alternative products (Low \& Lamb Jr., 2000), also seems an important indicator of industrial brand equity. Brand associations, reflecting non-product related associations evoked by the brand, play an important role in consumer branding and the 
facilitation of brand extensions. Industrial brands, however, are rarely if ever used to evoke non-product related associations. Therefore brand associations are not considered in this study.

Brand loyalty, although often viewed as a source, dimension or indicator of brand equity (Aaker, 1991; Keller, 1993; Keller, 1998), will be conceptualized as a desired outcome of brand equity. Brand loyalty refers to the tendency to be loyal to a brand, demonstrated by the intention to buy the brand as primary choice (Yoo \& Donthu, 2001). Brand loyalty can be defined in either behavioral or attitudinal terms. Behavioral - or purchase loyalty consists of repeated purchases of the brand. Attitudinal loyalty refers to the degree of dispositional commitment in terms of some unique value associated with the brand (Chaudhuri \& Holbrook, 2001). Effects on loyalty and purchasing intentions of two related, though separable categories of brand equity can generally be investigated in an industrial context. Industrial products are often individually branded, i.e. the product brand is distinct from the corporate brand. This leads to the following hypothesis:

H1: A direct positive relationship exists between product brand equity and repeat purchasing and loyalty intentions.

On the other hand, the company manufacturing the product will have built a corporate reputation and associated corporate brand equity. This is partially driven by factors independent of specific individual products (e.g. stock performance, corporate governance, and corporate promotional efforts), and partially driven by individual product brand equity. Corporate brand equity will directly influence repeat purchase intentions as a purchasing risk reducer. At the same time, product brand equity will also affect repeat purchasing intentions indirectly, through its effect on corporate brand equity. This leads to the following hypotheses: 
H2: A direct positive relationship exists between corporate brand equity and repeat purchasing and loyalty intentions.

H3: A positive relationship exists between product brand equity and corporate brand equity.

\subsection{Antecedents of Brand Equity}

In consumer research, brand equity has been related to expenditures in the dimensions of the marketing mix (Yoo et al., 2000). In the present study the relevance of several marketing mix dimensions for the creation of industrial brand equity will be investigated. Antecedents of the two distinct components of industrial brand equity (product and corporate) need to be identified. In previous studies, quality (Bendixen et al., 2004), or more specifically performance components (Mudambi et al., 1997), have been identified as the main drivers of industrial brand equity. That is, assessments of the product, the supplier of the product, and any other variables involved in the purchase and use of the product (Gordon et al., 1993). Drivers identified in previous studies were: physical product attributes, distribution services (ordering and delivery), and support services. Because the performance and perceived quality of products (Abratt, 1986; Michell et al., 2001) are crucial in an industrial context, overall satisfaction with the product will be the main driver of product brand equity:

H4: A direct positive effect of overall satisfaction with the product exists on product brand equity.

In an industrial context, price is often viewed as the most important purchasing decision criterion, while others estimate that price accounts for not more than $70 \%$ of the final decision (Mudambi et al., 1997). However, quality can be considered equally important as price (Alvarez \& Galera, 2001). Perceived value is therefore a significant 
concept in industrial markets. It is important that the perceived value by the buyer exceeds the price. Therefore:

H5: A higher perceived value for money is associated with higher levels of satisfaction with the product.

Distribution performance plays an important role in creating satisfaction with a product in industrial markets (Mudambi et al., 1997). Distribution entails all aspects of ordering, availability and delivery. Distributors and end-users evaluate industrial suppliers on their distribution performance. It may therefore be expected that:

H6: The perceived quality of the distribution of a product is positively associated with overall satisfaction with the product.

Buyers indicate that service is important to them, even to the point where they are willing to pay more for what they perceive to be superior service (Duckler, 2001). Service quality, together with the product's physical quality, increasingly form the basis for competitive advantage (Alvarez \& Galera, 2001). Other research has also confirmed the importance of quality support services (e.g. Mudambi et al., 1997). We therefore expect:

H7: Service quality is positively associated with the corporate brand.

To make good purchase decisions, industrial buyers need information. In the past, industrial markets were characterized by asymmetric information: Sellers had more information than buyers. With the increased use of the Internet this situation is changing. Buyers are able to get more and more information, not only through brochures or salespeople, but also by means of online information (Sharma et al., 2001). Therefore: 
H8: Providing better information is associated with a higher level of satisfaction with service.

For many industrial products, the need to have face-to-face interaction between buyer and seller is fundamental to the buyers' satisfaction. Where products are complex, or high in value, buyers expect value-added relationships. Purchase decisions depend not only on the evaluation of the functional benefits of the product itself, but also on the assessment of the people in the company behind it, their skills, attitudes, behaviors, mode of communication, etc. (Gordon et al., 1993). All contacts with the supplier will indirectly contribute to the buyer's knowledge and perception of the corporate brand (Davis, 2000). It is likely that buyers associate employees with superior skills with a higher level of service quality. As a result we expect:

H9: Better skilled employees are associated with a higher level of satisfaction with service.

The propositions were summarized in a conceptual model, visualized in Fig. 1.

\section{Please Insert Fig. 1 Here}

\section{Research Design}

The model was validated with data collected from industrial customers of a multinational specialty chemical company, owning over 1000 product brands. An industrial brand in the category "high performance engineering plastics", used primarily in the electrical/electronic- and automotive industry was investigated. To increase the external validity of our study, in-depth interviews were conducted with eleven purchasing engineers in the UK, Germany, France, Belgium, and the Netherlands. These interviews confirmed that, in varying degrees, Product, Price, Promotion, Place, and People contribute to the creation of industrial brand equity. 


\subsection{Questionnaire Development}

Based on previous research and the interviews, a questionnaire was developed. Items were measured as self-reported assessments of statements, evaluated on a 7-point Likert scale. The questionnaire was made available online.

\section{2. $\quad$ Sampling}

With the support of company sales representatives, an invitation to participate in the survey was sent to buyers in Europe, the US, and Asia. The response rate was 8.8\%, with 36 respondents from Europe, 18 from the US, and 13 from Asia, and 8 from elsewhere $(n=75) .37$ were active in the electrical/electronics industry, 26 in the automotive industry, and 12 were active in various other industries. $60 \%$ of the respondents were engineers.

\subsection{Analysis and Results}

The data were screened for multivariate outliers by calculating the Mahalanobis

$\mathrm{D}^{2}$, comparing the position of each value with the center of all observations. No outliers were identified. Distributions of all variables were tested for normality. No aberrations were detected. Several factor analyses were performed to reduce the number of variables. Based on the results of factor analyses, the multi-item scales were summated. Item loadings, means and standard deviations are presented in Table 1.

\section{Please Insert Table 1 Here}

Correlations were calculated between the factors. Correlations and descriptive statistics for the resulting factors are presented in Table 2.

\section{Please Insert Table 2 Here}

Regression analyses were then performed on the data. Equations are represented by:

(1) $\mathrm{PROD}=\alpha_{0}+\beta_{1} \mathrm{VAL}+\beta_{2} \mathrm{DIS}+\varepsilon_{1}$ 
(2) $\mathrm{SERV}=\alpha_{1}+\beta_{3} \mathrm{INFO}+\beta_{4} \mathrm{PERS}+\varepsilon_{2}$

(3) $\mathrm{PBE}=\alpha_{2}+\beta_{5} \mathrm{PROD}+\varepsilon_{3}$

(4) $\mathrm{CBE}=\alpha_{3}+\beta_{6} \mathrm{SERV}+\beta_{7} \mathrm{PBE}+\varepsilon_{4}$

(5) $\mathrm{LOY}=\alpha_{4}+\beta_{8} \mathrm{PBE}+\beta_{9} \mathrm{CBE}+\varepsilon_{5}$

In each equation, $\alpha$ represents the intercept and $\varepsilon$ the error term. Partial Least Squares (PLS) regression was used to simultaneously estimate all relationships put forward in the conceptual model. The reasons to opt for PLS are threefold. First, PLS allows estimation of structural models for relatively small sample sizes (Chin \& Newsted, 1999). Second, given the exploratory nature of the research and an emphasis on theory development, PLS is particularly useful given its prediction-oriented nature (Barclay et al., 1995; Fornell \& Cha, 1994). Third, by opting for PLS potential problems due to multicollinearity were avoided (Ryan et al., 1999). Given the significant correlations among predictor variables in our model the possible distorting consequences of multicollinearity cannot be ignored. Results are presented in Table 3.

\section{Please Insert Table 3 Here}

From Table 3 it can be concluded that all hypotheses are supported by the data. This implies that the model is validated by the sample.

\section{Conclusion}

Brand equity appears to play a significant role in industrial branding. It was conceptualized as the result of past investments in the 5 P's of the marketing mix. That is, investments in product, place, people, promotion and price. In the business-tobusiness context, promotion was interpreted as providing information. Buyers' perceptions about the 5P's have an influence on the way they perceive and evaluate the brand. This, in turn, has an effect on their purchase decisions. By investing in the 5P's, 
companies create brand awareness and a positive brand image. In this way, brand equity and loyalty are created. Two interrelated components of brand equity were distinguished: product brand equity and corporate brand equity.

The results show that product brand equity is mostly influenced by physical product attributes and distribution. Employees and information played a lesser role. Corporate brand equity is mostly determined by service attributes, and employees. Here distribution and value did not play a direct role. In terms of direct effects, the corporate brand seems to be slightly more important in industrial markets than the individual product brand; however, the product brand contributes not only directly to behavioral intentions, but also indirectly via corporate brand equity.

\subsection{Managerial Implications}

For managers it is important to realize that the proposed antecedents of the two components of industrial brand equity (Product Brand Equity and Corporate Brand Equity) correspond with the P's of the marketing mix: product, place, promotion, price and people. The 5P's are usually fully controlled by the company in order to facilitate exchange. The study therefore confirmed that brand equity can be explained as a result of past investments in the marketing of the brand (Keller, 1998).

It is also evident from the study that industrial companies can benefit from investing in their brands and from the resulting brand equity. Tentatively, the following recommendations can be made for industrial companies who wish to build and benefit from brand equity:

In order to build a strong industrial product brand, companies should 1) focus their efforts on buyers' perceptions of the product. Buyers should perceive the product as high quality, dependable, consistent and innovative; 2) create favorable perceptions 
with respect to the development lead-time of the product; 3) offer value for money; 4) invest in reliable distribution. These associations help to create a strong product image.

Besides a favorable perception of the product, a favorable impression of the employees will aid the company in creating a strong corporate brand. Apparently buyers associate the service they receive with the company.

A major finding in this study is the importance of corporate brand names. Loyalty to a product is partially driven by a strong corporate brand.

Industrial branding, in terms of image creation, competitive differentiation, and buyer recognition, could be no less beneficial, and no more difficult to achieve for industrial companies than for B2C companies (Shipley \& Howard, 1993).

\subsection{Limitations and Suggestions for Further Research}

A number of limitations pertain to this study. First, it focused exclusively on a single industrial market: specialty chemicals. Furthermore, the relatively small sample prohibits the full generalizability of the conclusions. The findings can be generalized cautiously to markets similar to the one studied. Research is needed on the determinants of industrial brand equity for a broad range of industrial markets. Another issue is that the sample of respondents consisted mainly of engineers. Previous research demonstrated that a variety of managers is involved in the purchasing process. In some cases companies may have established a formal buying center, in other cases the members may be part of an informal group. The number of people involved in the purchasing process and their positions may vary across organizations. In future research, besides engineers also other participants in the buying decision should be involved.

Acknowledgements: The authors would like to express their gratitude to Ivon Lenoir, who collected the data for this study. 
Aaker, D. A. (1991). Managing brand equity: Capitalizing on the value of a brand name. New York: The Free Press.

Aaker, D. A. (1996). Building strong brands. New York: Free Press.

Abratt, R. (1986). Industrial buying in high tech markets. Industrial Marketing Management, 15 (4), 293-298.

Alvarez, P., \& Galera, C. (2001). Industrial marketing applications of quantum measurement techniques. Industrial Marketing Management, 30 (1), 13-22.

Barclay, D., Higgins, C., \& Thompson, R. (1995). The partial least squares (pls) approach to causal modeling: Personal computer adoption and use as an illustration. Technology Studies, 2 (2), 285-309.

Bendixen, M., Bukasa, K. A., \& Abratt, R. (2004). Brand equity in the business-tobusiness market. Industrial Marketing Management, in press.

Chaudhuri, A., \& Holbrook, M. B. (2001). The chain of effects from brand trust and brand affect to brand performance: The role of brand loyalty. Journal of Marketing, 65 (2), 81-93.

Chin, W. W., \& Newsted, P. R. (1999). Structural equation modeling analysis with small sample research. In R. R. Hoyle (Ed.), Statistical strategies for small sample research (pp. 307-341). Thousand Oaks, CA: Sage.

Davis, S. M. (2000). The power of the brand. Strategy and Leadership, 28 (4), 4-9.

Duckler, M. (2001). Price, quality: Only part of the value. Marketing News, 35 (10), 1720.

Fornell, C., \& Cha, J. (1994). Partial least squares. In R. P. Bagozzi (Ed.), Advanced methods of marketing research (pp. 52-78). Oxford: Blackwell. 
Gordon, G. I., Calantone, R. J., \& Di Benetto, C. A. (1993). Brand equity in the business-to-business sector: An exploratory study. Journal of Product and Brand Management, 2 (3), 4-16.

Hunter, L. M., Kasouf, C. J., Celuch, K. G., \& Curry, K. A. (2004). A classification of business-to-business buying decisions: Risk importance and probability as a framework for e-business benefits. Industrial Marketing Management, 33 (2), $145-154$.

Hutton, J. G. (1997). A study of brand equity in an organizational-buying context. Journal of Product and Brand Management, 6 (6), 428-39.

Interbrand (2003). The best global brands: 2003 global brands scoreboard. Business Week Online (September, 8).

Keller, K. L. (1993). Conceptualizing, measuring, and managing customer-based brand equity. Journal of Marketing, 57 (1), 1-22.

Keller, K. L. (1998). Strategic brand management: Building, measuring, and managing brand equity. Upper Saddle River, NJ: Prentice Hall.

Kumar, V., Bohling, T. R., \& Ladda, R. N. (2003). Antecedents and consequences of relationship intention: Implications for transaction and relationship marketing. Industrial Marketing Management, 32 (8), 667-676.

Lassar, W. M., Mittal, B., \& Sharma, A. (1995). Measuring customer-based brand equity. Journal of Consumer Marketing, 12 (4), 11-19.

Low, G. S., \& Lamb Jr., C. W. (2000). The measurement and dimensionality of brand associations. Journal of Product and Brand Management, 9 (6), 350-368.

Low, J., \& Blois, K. (2002). The evolution of generic brands in industrial markets: The challenges to owners of brand equity. Industrial Marketing Management, 31 (5), 385-392. 
Michell, P., King, J., \& Reast, J. (2001). Brand values related to industrial products. Industrial Marketing Management, 30 (5), 415-425.

Mudambi, S. (2002). Branding importance in business-to-business markets: Three buyer clusters. Industrial Marketing Management, 31 (6), 525-533.

Mudambi, S. M., Doyle, P., \& Wong, V. (1997). An exploration of branding in industrial markets. Industrial Marketing Management, 26 (5), 433-446.

Ryan, M. J., Rayner, R., \& Morrison, A. (1999). Diagnosing customer loyalty drivers: Partial least squares vs. regression. Marketing Research, 11 (2), 19-26.

Sharma, A., Krishnan, R., \& Grewal, D. (2001). Value creation in markets: A critical area of focus for business-to-business markets. Industrial Marketing Management, 30 (4), 391-402.

Shipley, D., \& Howard, P. (1993). Brand-naming industrial products. Industrial Marketing Management, 22 (1), 59-66.

Ulaga, W., \& Chacour, S. (2001). Measuring customer-perceived value in business markets: A prerequisite for marketing strategy development and implementation. Industrial Marketing Management, 30 (6), 525-540.

Wood, L. (2000). Brand and brand equity: Definition and management. Management Decision, 38 (9), 662-669.

Yoo, B., Donthu, N., \& Lee, S. (2000). An examination of selected marketing mix elements and brand equity. Journal of the Academy of Marketing Science, 28 (2), 195-212.

Yoo, B., \& Donthu, N. (2001). Developing and validating a multidimensional consumer-based brand equity scale. Journal of Business Research, 52 (1), 1-14. 
Allard C.R. van Riel, an assistant professor of logistics and marketing at Maastricht University, does research in industrial relations, service innovation, branding, and decision-making under uncertainty. He published articles in The Journal of Service Research, International Journal of Service Industry Management, Total Quality Management and European Management Journal, and contributed several book chapters.

Charles Pahud de Mortanges, an associate professor of marketing at Maastricht University, does research in branding and global marketing. He published articles in The European Management Journal, Journal of International Consumer Marketing, Asia Pacific Journal of Marketing and Logistics, International Business Review, European Journal of Marketing, and Journal of International Business Studies.

Sandra Streukens is a $\mathrm{PhD}$ candidate in the marketing department at Maastricht University. She published articles in Journal of Business Research, Advances in Consumer Research, Journal of Economic Psychology, and the International Journal of Service Industry Management. 
Table 1

Composition of measures, and item descriptive statistics

\begin{tabular}{|c|c|c|c|}
\hline$\frac{\text { Factor }}{\text { Item }}$ Reliability $(\alpha)$; EigenValue; Variance explained) & $\begin{array}{c}\text { Std. } \\
\text { Loading }\end{array}$ & Mean & Std Dev. \\
\hline \multicolumn{4}{|l|}{ Product Quality $(\alpha=.83 ; \mathrm{EV}=4.11 ; \mathrm{VAR}=58.75 \%)$} \\
\hline Product $\mathrm{X}$ is a high quality product & .80 & 5.60 & 1.23 \\
\hline Product $\mathrm{X}$ development lead time is excellent & .75 & 4.77 & 1.24 \\
\hline Product $\mathrm{X}$ is a dependable and consistent product & .85 & 5.26 & 1.34 \\
\hline Product $\mathrm{X}$ is an innovative product & .90 & 4.92 & 1.39 \\
\hline \multicolumn{4}{|l|}{ Service Quality $(\alpha=.80 ; \mathrm{EV}=1.59 ; \mathrm{VAR}=22.70 \%)$} \\
\hline The technical support of Product $\mathrm{X}$ is excellent & .93 & 5.15 & 1.84 \\
\hline We are satisfied with production support for Product X & .96 & 5.16 & 1.60 \\
\hline We are satisfied with development support for Product $X$ & .90 & 5.13 & 1.69 \\
\hline \multicolumn{4}{|l|}{ Product Distribution $(\alpha=.89 ; \mathrm{EV}=3.07 ; \mathrm{VAR}=43.85 \%)$} \\
\hline Ordering product $\mathrm{X}$ is convenient & .86 & 5.59 & 1.31 \\
\hline Product $\mathrm{X}$ is available when we need it & .92 & 4.93 & 1.42 \\
\hline Product $\mathrm{X}$ is available where we need it & .91 & 5.11 & 1.47 \\
\hline Product $\mathrm{X}$ is supplied in a reliable way & .78 & 5.18 & 1.61 \\
\hline \multicolumn{4}{|l|}{ Product Value $(\alpha=.80 ; \mathrm{EV}=2.13 ; \mathrm{VAR}=30.49 \%)$} \\
\hline Product X reduces production costs & .83 & 4.10 & 1.51 \\
\hline Product $\mathrm{X}$ offers value for money & .78 & 4.48 & 1.31 \\
\hline Product $X$ reduces systems costs & .88 & 3.83 & 1.56 \\
\hline \multicolumn{4}{|l|}{ Service Personnel $(\alpha=.86 ; 1.46 ;$ VAR $=16.18 \%)$} \\
\hline Company Y has highly skilled employees & 67 & 5.61 & 1.28 \\
\hline Company Y staff is well dressed and appear neat & 69 & 5.70 & 1.37 \\
\hline I can trust Company Y staff & .90 & 5.66 & 1.28 \\
\hline Company $\mathrm{Y}$ staff is always willing to help buyers & .91 & 5.92 & 1.18 \\
\hline \multicolumn{4}{|l|}{ Information Services $(\alpha=.92 ; \mathrm{EV}=5.90 ; \mathrm{VAR}=65.58 \%)$} \\
\hline Service staff understands our needs & .78 & 5.10 & 1.65 \\
\hline We are satisfied with the Information about Product $X$ & .91 & 4.97 & 1.67 \\
\hline On-line information about Product $\mathrm{X}$ is of good quality & .91 & 4.41 & 1.77 \\
\hline The documentation of Product $\mathrm{X}$ is of good quality & .90 & 4.83 & 1.78 \\
\hline If I request supplementary info about Product X, I receive it quickly & .89 & 5.19 & 1.71 \\
\hline \multicolumn{4}{|l|}{ Product Brand Equity $(\alpha=.77 ; \mathrm{EV}=1.33 ; \mathrm{VAR}=16.59 \%)$} \\
\hline Product $\mathrm{X}$ generally has a good reputation & .89 & 5.22 & 1.19 \\
\hline Rate Product X's reputation on a scale (1 to 7 ) & .93 & 5.17 & 1.12 \\
\hline Product $\mathrm{X}$ is a well-known name in the market & .58 & 4.93 & 1.66 \\
\hline \multicolumn{4}{|l|}{ Corporate Brand Equity $(\alpha=.85 ; \mathrm{EV}=4.22 ; \mathrm{VAR}=52.76 \%)$} \\
\hline Company $\mathrm{Y}$ is a financially stable company & .86 & 5.44 & 1.18 \\
\hline Company $\mathrm{Y}$ is a leading edge supplier & .72 & 4.97 & 1.27 \\
\hline Company $\mathrm{Y}$ is a well known name around the world & .78 & 5.18 & 1.34 \\
\hline The fact that Company Y produced Product X certainly adds value & .85 & 5.05 & 1.23 \\
\hline The fact that Company Y produces Product $\mathrm{X}$ is important to me & .72 & 5.09 & 1.34 \\
\hline \multicolumn{4}{|l|}{ Loyalty $(\alpha=.89 ; \mathrm{EV}=3.90 ; \mathrm{VAR}=64.92 \%)$} \\
\hline Overall we are very satisfied with Product X & .72 & 5.03 & 1.40 \\
\hline Overall we are very satisfied with Company $Y$ & .84 & 5.31 & 1.27 \\
\hline If asked, we would recommend Product X & .81 & 5.12 & 1.35 \\
\hline If asked, we would recommend Company $\mathrm{Y}$ & .84 & 5.36 & 1.36 \\
\hline We intend to use Product $\mathrm{X}$ again in the future & .81 & 5.59 & 1.30 \\
\hline We intend to do business again with Company $\mathrm{Y}$ in the future & .81 & 5.66 & 1.37 \\
\hline
\end{tabular}


Table 2

Descriptive statistics: Means, standard deviations and Pearson correlations among constructs

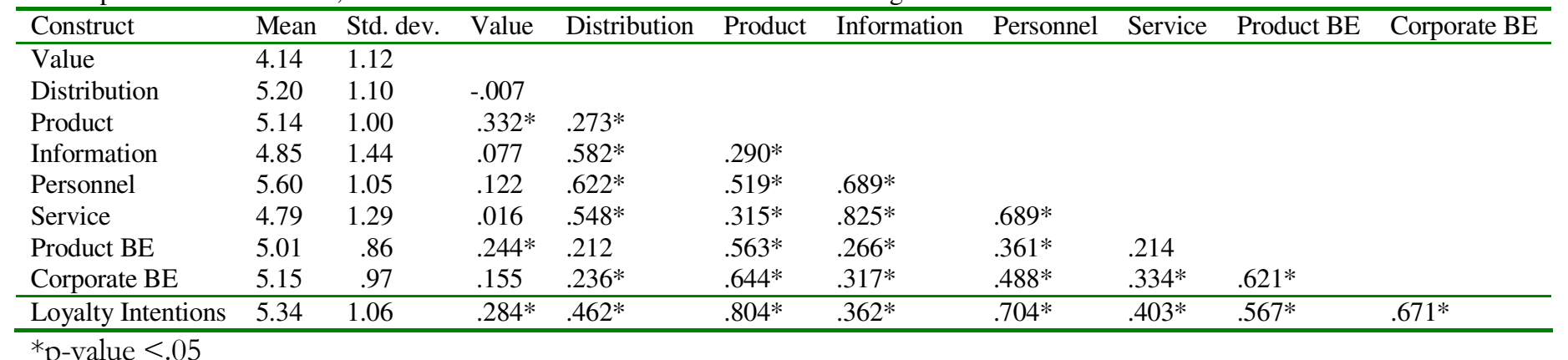

$*_{\text {p-value }<.05}$ 
Table 3

\begin{tabular}{|c|c|c|c|c|c|c|}
\hline Eq. & Model fit & Relationship & Coefficient & T-Value & p-Value & Conclusion \\
\hline \multirow[t]{2}{*}{ (1) } & $\mathrm{R}^{2}=0.36 ; \mathrm{F}_{2,75}=21.09(\mathrm{p}<0.0001)$ & $\mathrm{VAL} \rightarrow \mathrm{PROD}$ & 0.51 & 5.11 & $<0.0001$ & Supports H5 \\
\hline & & $\mathrm{DIS} \rightarrow \mathrm{PROD}$ & 0.32 & 2.05 & 0.0438 & Supports H6 \\
\hline \multirow[t]{2}{*}{ (2) } & $\mathrm{R}^{2}=0.81 ; \mathrm{F}_{2,75}=159.87(\mathrm{p}<0.0001)$ & $\mathrm{INFO} \rightarrow \mathrm{SERV}$ & 0.58 & 5.34 & $<0.0001$ & Supports H8 \\
\hline & & PERS $\rightarrow$ SERV & 0.38 & 3.24 & 0.0018 & Supports H9 \\
\hline (3) & $\mathrm{R}^{2}=0.54 ; \mathrm{F}_{1,75}=89.22(\mathrm{p}<0.0001)$ & $\mathrm{PROD} \rightarrow \mathrm{PBE}$ & 0.72 & 9.37 & $<0.0001$ & Supports H4 \\
\hline \multirow[t]{2}{*}{ (4) } & $\mathrm{R}^{2}=0.50 ; \mathrm{F}_{2,75}=37.50(\mathrm{p}<0.0001)$ & $\mathrm{SERV} \rightarrow \mathrm{CBE}$ & 0.18 & 2.07 & 0.04185 & Supports H7 \\
\hline & & $\mathrm{PBE} \rightarrow \mathrm{CBE}$ & 0.64 & 7.49 & $<0.0001$ & Supports H3 \\
\hline \multirow[t]{2}{*}{ (5) } & $\mathrm{R}^{2}=0.56 ; \mathrm{F}_{2,75}=47.73(\mathrm{p}<0.0001)$ & $\mathrm{PBE} \rightarrow \mathrm{LOY}$ & 0.38 & 3.26 & 0.00167 & Supports H1 \\
\hline & & $\mathrm{CBE} \rightarrow \mathrm{LOY}$ & 0.42 & 3.69 & 0.00042 & Supports H2 \\
\hline
\end{tabular}


Figure 1: A Proposed Model for Measuring Industrial Brand Equity

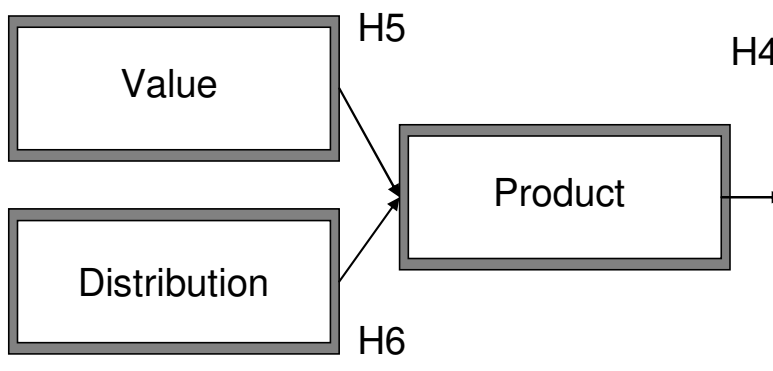

$\mathrm{H} 4$

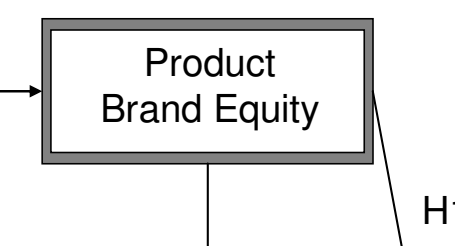

Industrial Marketing Efforts

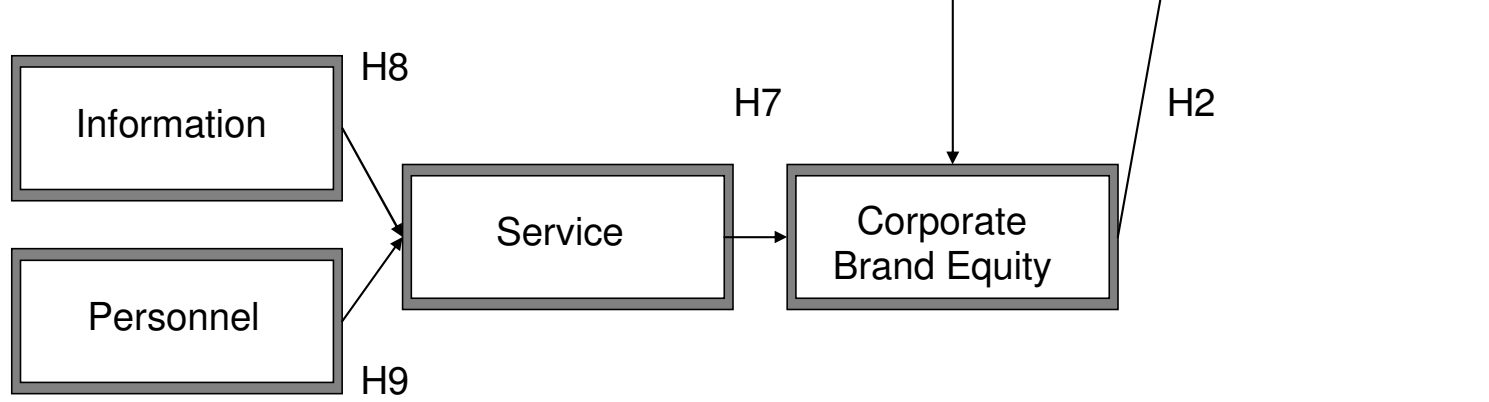

